\title{
Topographic controls on dike injection in volcanic rift zones
}

\author{
Mark D. Behn ${ }^{1 *}$, W. Roger Buck², and I. Selwyn Sacks ${ }^{3}$ \\ ${ }^{1}$ Department of Geology and Geophysics, Woods Hole Oceanographic Institution, Woods \\ Hole, MA 02543 USA \\ ${ }^{2}$ Lamont Doherty Earth Observatory, Columbia University, Palisades, NY 10964 USA \\ ${ }^{3}$ Department of Terrestrial Magnetism, Carnegie Institution of Washington, Washington, \\ DC 20015 USA
}

\begin{abstract}
:
Dike emplacement in volcanic rift zones is often associated with the injection of "bladelike" dikes, which propagate long distances parallel to the rift, but frequently remain trapped at depth and erupt only near the tip of the dike. Over geologic time, this style of dike injection implies that a greater percentage of extension is accommodated by magma accretion at depth than near the surface. In this study, we investigate the evolution of faulting, topography, and stress state in volcanic rift zones using a kinematic model for dike injection in an extending 2-D elastic-viscoplastic layer. We show that the intrusion of blade-like dikes focuses deformation at the rift axis, leading to the formation of an axial rift valley. However, flexure associated with the development of the rift topography generates compression at the base of the plate. If the magnitude of these deviatoric compressive stresses exceeds the deviatoric tensile stress associated with far-field extension, further dike injection will be inhibited. In general, this transition from tensile to compressive deviatoric stresses occurs when the rate of accretion in the lower crust is greater than $50-60 \%$ of the far-field extension rate. These results indicate that over geologic time-scales the injection of blade-like dikes is a self-limiting process in which dike-generated faulting and topography result in an efficient feedback mechanism that controls the time-averaged distribution of magma accretion within the crust.
\end{abstract}

Key Words: Dike intrusion, faulting, rifting, mid-ocean ridge, topographic stress

*Corresponding Author, Dept. of Geology and Geophysics, Woods Hole Oceanographic Institution, 360 Woods Hole Road MS \#22, Woods Hole, MA 02543, email: mbehn@ whoi.edu, phone: 508-289-3637, fax: 508-457-2187. 


\section{Introduction}

Extension in volcanic rift zones is accommodated through a combination of normal faulting and local magma intrusion. Dike emplacement in these environments is often characterized by "blade-like" dikes (identified by their large length-to-height ratios), which propagate outward from a central magma reservoir parallel to the strike of the rift (Figure 1). Surface eruptions associated with blade-like dikes are primarily concentrated near the tip of the dike [1], implying that they form in a stress regime that favors lateral propagation rather than upward growth and eruption [2]. Dikes will tend to propagate laterally if the driving pressure (defined as the difference between the magma pressure, $\mathrm{P}_{\text {magma }}$, and the total horizontal stress in the lithosphere, $\sigma_{\text {tectonic }}$ ) at the dike center exceeds the driving pressure at the top and bottom of the dike [2, 3]. Ryan [4] hypothesized that lateral propagation will occur at the level of effective neutral buoyancy. In regions where magma supply is continuous, this level is determined by the vertical density structure of the crust. However, where the rate of magma injection is less than the rate of extension, the level of effective neutral buoyancy is controlled by a combination of rock and magma density, local stress state and magma pressure, and broadly corresponds to the depth of the brittle ductile transition [2]. Therefore, in magma limited environments we consider such dikes to be "double-edged" blades limited at the top by brittle failure and below by viscous creep. Excellent examples of magma limited volcanic rift zones are slowspreading mid-ocean ridges, where seismic moment studies [5] and measurements of cumulative fault throw [6] suggest that $\sim 80 \%$ of seafloor spreading is accommodated by magmatic accretion, while the remaining $20 \%$ occurs via extensional faulting.

Dike intrusion has a strong influence on faulting and topographic relief during rifting. Regions overlying zones of dike emplacement are characterized by normal faulting, subsidence, and graben formation (e.g., [7-10]). For example, individual diking events in Iceland have been observed to produce up to $2 \mathrm{~m}$ of co-intrusion slip on normal faults with little or no lava eruption $[11,12]$. Moreover, the 1-2-km deep rift valley observed along many parts of the slow-spreading Mid-Atlantic ridge (e.g., [13, 14]), illustrates the potential for continual magma injection to produce significant rift topography [10]. However, while the mechanical interaction between magma injection and faulting has 
been studied on the timescale of individual dikes [7, 8, 15-18], little work has been done to understand how these processes will evolve over geologic time.

In this study, we investigate the feedbacks between dike emplacement, faulting, and the growth of topography in volcanic rift zones. Dike intrusion is simulated using an elastic-viscoplastic continuum approach that allows us to model strain localization without presupposing the initial location of faults. We show that the emplacement of blade-like dikes rapidly localizes strain onto inward dipping faults, resulting in the formation of an axial rift valley. However, as topography grows, compressional stresses associated with plate flexure accumulate at the ridge axis, which will suppress the injection of future dikes. The result is an efficient feedback mechanism in which dikeinduced faulting and topography act to control the time-averaged depth distribution of magma accretion in the crust.

\section{Numerical Models of Volcanic Rifting}

Most previous studies that examined the mechanical interaction between magma injection and faulting assumed that the Earth behaves as an elastic half-space and simulated faulting through induced slip on presupposed dislocations in the crust (e.g., [7, $8,15])$. These assumptions are likely valid on short timescales, but breakdown in the case of repeated diking events over geologic time. Here we study the long-term evolution of topography and faulting at volcanic rifts in a 2-D elastic-viscoplastic layer (Figure 2) using the Fast Lagrangian Analysis of Continua (FLAC) technique of Cundall [19]. This numerical approach has been used to simulate localized deformation (i.e., faulting) in a variety of extensional environments [20-22] and is described in detail elsewhere [23, 24].

In our model, material behavior is a function of the thermal structure, stress, and accumulated plastic strain throughout the model space. In regions where deformation is visco-elastic, the material behaves as a Maxwell solid. Viscous deformation is incompressible and follows a non-Newtonian temperature and strain-rate dependent power-law [25, 26]. Material properties appropriate for a dry diabase rheology [27] are assumed throughout the model space. Plastic yielding in the brittle layer is controlled by Mohr-Coulomb theory. The weakening of the brittle layer after failure is simulated by 
assuming a strain-dependent cohesion law in which the initial cohesion, $\mathrm{C}_{\mathrm{o}}$, decreases linearly with the total accumulated plastic strain until it reaches a minimum value, $\mathrm{C}_{\min }$, after a critical increment of plastic strain of $\varepsilon_{\mathrm{c}}[21,22,24]$. For the model runs presented in this study we assume $\mathrm{C}_{\mathrm{o}}=24 \mathrm{MPa}$ and $\mathrm{C}_{\min }=4 \mathrm{MPa}$, however we note that these parameters have little influence on our numerical results relative to the effects of dike injection.

The initial numerical domain is $100 \mathrm{~km}$ wide by $20 \mathrm{~km}$ deep, with a grid resolution of $0.25 \mathrm{~km} \times 0.25 \mathrm{~km}$. Deformation is driven by imposing a uniform far-field extension along the edges of the model space with a velocity, $u_{\text {tectonic }}=2.5 \mathrm{~cm} / \mathrm{yr}$ (Figure 2 ). A hydrostatic boundary condition is assumed for the base of the model space and the top boundary is stress free. The thickness of the brittle layer, $\mathrm{h}_{\text {lith }}$, corresponds to the depth of the brittle ductile transition $\left(\sim 650^{\circ} \mathrm{C}\right.$ for dry gabbroic rock [28]) and is adjusted through the imposed thermal structure. Temperature increases linearly with depth from $0^{\circ} \mathrm{C}$ at the surface to the $650^{\circ} \mathrm{C}$ at $h_{\text {lith }}$, below which it increases rapidly to a maximum of $1200^{\circ} \mathrm{C}$. This temperature structure results in a sharp brittle ductile transition, minimizing the effect of viscous strengthening in the lower crust. To ensure that rift behavior is not affected by necking associated with perturbations in lithospheric thickness all calculations assume a uniform initial plate thickness of $6 \mathrm{~km}$. For simplicity temperature structure remains fixed and does not evolve throughout our numerical calculations.

Assuming blade-like dikes represent the dominant style of intrusion in magma limited volcanic rifts such as slow-spreading ridges, a greater fraction of magma will be intruded at depth than near the surface (e.g., Figure 1, [2]). We simulate this process kinematically, by widening a column of model elements extending from the base of the brittle layer to a fixed depth, d, below the surface (Figure 2). Here we envision that magma is supplied to the injection zone by along-rift transport from a central magma chamber as illustrated in Figure 1. As deformation progresses, d, remains fixed with respect to the surface and thus may migrate relative to the fixed thermal structure. The rate of injection is described by the parameter $\mathrm{M}$, which is defined as the ratio of the rate of dike opening to the rate of far-field extension applied on either side of the model space [29]. Thus, $M=1$ corresponds to a case where the rate of dike opening is equal to the 
rate of far-field extension, and $\mathrm{M}=0$ represents an amagmatic rift. In the following section we describe the response of the lithosphere and the growth of rift-valley topography to different rates of magma injection.

We have benchmarked our approach against the 2-D boundary element solution for an opening dike in an elastic half-space [30]. The predicted vertical and horizontal surface displacements closely reproduce the boundary element solution (Figures 3a \& $3 b$ ), with slight differences resulting from the finite width of the injection zone and the finite thickness of the elastic plate. The predicted deviatoric stresses are illustrated in Figure $3 \mathrm{c}$, and show the expected regions of compression adjacent to the dike and tension above and below the dike.

\section{Stress Evolution and the Growth of Rift Valley Topography}

In all simulations with dike injection (i.e., $\mathrm{M}>0$ ), deformation initiates on two inward-dipping normal faults that form at the top of the dike zone and propagate upward to the surface (note that for $\mathrm{M}=0$ initial deformation will be distributed throughout the brittle layer). The location of these inward-dipping faults corresponds to the region of maximum tensile stress predicted by calculations of a dike in an elastic half-space (e.g., Figure $3 c$ and ref. [7]). The initial growth of topography is a function of both the rate of magma injection and the depth distribution of accretion throughout the crust. When dike injection penetrates to shallow depths, the rift valley subsides more rapidly for smaller rates of magma injection (Figure 4). In contrast, if the region of dike injection is confined to deeper levels in the crust, the rate of topographic growth increases with greater rates of magma injection. These calculations indicate that both the depth distribution of magma injection, as well as the rate of injection are important in rift valley development.

For $\mathrm{M}>\sim 0.5$, the inward-dipping normal faults remain pinned at the top of the dike creating a small "key-stone" block that does not deform as the rift valley deepens (Figure $5 a, b)$. In these runs the long-term depth of the rift valley is limited by the development of off-axis faults, which alleviate flexural bending stresses in the uplifted rift flanks [31]. For cases with $\mathrm{M}<\sim 0.5$, a conjugate set of faults forms dipping outward from the axis and cutting the entire brittle layer (Figure 5c,d). These conjugate faults relieve tensile 
stresses that accumulate in the lower portion of the plate adjacent to the dike. The formation of the conjugate faults produces a wider and shallower rift valley than for more magmatic cases in which only inward dipping faults are observed. Furthermore, as deformation continues alternating sets of inward and outward dipping faults form, resulting in a pattern of horst and graben topography that is not predicted from simple elastic models of dike injection. Although evidence for outward dipping faults is relatively rare at slow-spreading ridge segments, thickening of the lithosphere off-axis due to plate cooling will favor the formation of inward dipping faults as compared to the uniform thickness plate studied here [32].

Dike injection requires that the pressure in the dike is greater than the total horizontal stress in the lithosphere (see Figure 1 and $[2,3,33]$ ). Because magma chamber overpressures are typically small (0-10 MPa [e.g., 3]), this requires the horizontal deviatoric stress in the lithosphere to be tensile. As described above, our simulations assume a kinematic formulation for dike injection, in which there is no feedback between the modeled stress state and the depth distribution of magma injection at a particular time step. However, the calculated axial stresses can be used to assess whether conditions are consistent with continued dike intrusion. For example, if the horizontal deviatoric stress surrounding the injection zone remains tensile, further dike intrusion will be allowed. In contrast, the development of compressional deviatoric stresses will suppress continued dike intrusion.

For cases with low magma supply $(\mathrm{M}<0.5)$, we find that the horizontal deviatoric stress, $\sigma_{x x}$, in the plate remain tensile throughout the axial lithosphere (Figure $5 \mathrm{c}$ ). However, for higher rates of magma injection, compressional deviatoric stresses accumulate rapidly in the lower lithosphere adjacent to the dike injection zone (Figure 5b). Although compression is expected adjacent to an opening dike in an elastic halfspace (e.g., Figure 3 and ref. [7]), injection alone will not result in compression in an extending plate due to the net tensile stresses associated with the far-field boundary conditions. Rather, the deviatoric compression at the base of the plate develops in response to the formation of the axial rift valley. As rift topography grows flexural 
bending stresses caused by the uplifted rift flanks and depressed axial valley produce compression at the base of the lithosphere beneath the rift axis.

To illustrate the importance of rift topography on the stress at the rift axis we examined the evolution of stress throughout deformation for the $M=1$ simulation shown in Figures $5 \mathrm{a} \& \mathrm{~b}$. The component of the horizontal deviatoric stress associated with topography was estimated by calculating the flexural stresses in a 6-km-thick elastic plate loaded from above by the model rift topography [34]. Although this approach ignores complexities associated with variations in plate thickness and the evolving material properties of the lithosphere, it provides a good first order approximation for the flexural stresses associated with rift topography. Figure 6 illustrates the relationship between the growth of the rift valley, the topographic stresses predicted from flexure, and the horizontal deviatoric stress at the base of the plate beneath the rift axis. We find that for all time steps, the influence of the far-field boundary conditions is to reduce the deviatoric stress relative to the topographic stress. However, both the topographic and deviatoric stresses are directly correlated with the depth of the axial valley, and reach their respective maximum values only when the axial valley stops deepening (Figure 6).

The transition between compressional and tensile deviatoric stresses at the base of the plate occurs for $\mathrm{M} \approx 0.5$ (Figure 7 ). When $\mathrm{M}>0.5$, magma injection relieves the tensile stresses associated with far-field extension, causing the rift valley topography to dominate the stress state in the lithosphere. The compressional stresses in the lower lithosphere promote enhanced tensile faulting above the dike, which further deepens the rift valley leading to a positive feedback and greater compression at the base of the plate. Of course, it is unlikely that magma injection will continue in the presence of such large compressive stresses, and thus we view model runs with $\mathrm{M}>0.5$ to be unphysical on geologic time-scales. In contrast, when $M<0.5$, far-field extension dominates the stress state in the lithosphere. The result is net tension at all depths beneath the rift axis, which in turn promotes extensional faulting throughout the entire brittle layer. Conjugate outward dipping normal faults (e.g., Figure 5c) develop in response to these tensile stresses, producing a wider, shallower rift valley that further decreases the magnitude of the topographic stresses. 
One oversimplification of the models presented above is that we assume all dikes extend upward to a fixed depth. In reality, there will be a distribution in dike height through time, with some dikes reaching the surface and others stopping at various depths below the surface. To investigate the influence of these effects we examined two additional parameterizations for the depth distribution of magma. First, we simulated cases in which $\mathrm{M}$ increases linearly from 0 at the surface to values ranging from 0 to 1 at the bottom of the plate. Figure 7c illustrates the horizontal deviatoric stress at the base of the lithosphere after $5 \mathrm{~km}$ of total extension. Similar to the earlier calculations in which $\mathrm{M}$ was constant within the dike zone, we find that cases in which $\mathrm{M}$ varies by more than $\sim 0.6$ results in compressional deviatoric stresses below the axial valley. We further explored situations in which there was a linear variation in $M$ throughout the plate, but with $\mathrm{M}>0$ at the surface, implying a certain fraction of dikes erupt. These calculations again show that the transition between compressional and tensile deviatoric stress at the base of the plate occurs when the total variation in M exceeds 0.6-0.7 (Figure 7).

\section{Discussion and Conclusions}

Temporal and spatial variations in the rate of magma accretion are frequently invoked to explain differences in faulting and axial morphology at slow-spreading ridges $[29,35$, 36]. Regions with deep rift valleys are interpreted to reflect lower rates of magma injection, while shallower and more distributed rift morphology is taken to imply enhanced magmatism $[13,37]$. In this study we have shown that the depth-distribution of magma injection throughout the crust will also strongly influence topographic growth and long-term rift morphology. Specifically, larger gradients in the depth distribution of magma accretion will promote enhanced normal faulting in the shallow crust and the development of deeper rift valleys (Figure 7). Thus future interpretations of crustal magmatic processes from observed rift morphology, must involve a better understanding of how accretion occurs at depth.

There are strong feedbacks between dike injection, faulting, and the growth of rift topography. The calculations presented in this study illustrate the limitations of inferring lithospheric stress and dike propagation in an evolving rift zone from a simple yield strength envelope. As has been shown previously (e.g., [7]), the injection of blade-like 
dikes will promote normal faulting and graben subsidence. However, magma injection simultaneously relieves tensile stresses in the extending plate, leading to a situation in which rift topography dominates the overall stress state in the lithosphere (e.g., Figure 7). The result is an efficient negative feedback in which the deepening rift valley drives the base of the plate toward more compressive stresses, inhibiting further dike injection at these depths.

As the stress state near the base of the plate approaches lithostatic one of several scenarios will occur. The first is that dike propagation will cease until there has been sufficient far-field extension to reduce the total horizontal stress to the tectonic stress curve shown in Figure 1. A second possibility is that as the total horizontal stress approaches lithostatic, dikes will propagate to shallower depths, redistributing magma injection throughout the crust (Figure 8). In this scenario, dikes are initially "doubleedged" - limited both above and below by the variation in tectonic stress. However, as dikes are forced to shallower levels in the crust they will eventually become "singleedged" - narrowing at the base and widening at the surface. Both of these scenarios result in mechanisms in which the time-averaged gradient in magma accretion evolves in such a way that the deviatoric stress state beneath the rift axis remains tensile (i.e. $\Delta \mathrm{M}<$ 0.5-0.7 in Figure 7c). These processes may occur in a time-averaged manner such that a combination of double-edged and single-edged dikes are continuously injected. Alternatively, injection may cycle between periods in which double-bladed dikes are intruded, followed by periods of single-bladed dikes. Future studies in which dike injection is linked to the evolving stress state in the lithosphere, as well to the flux and migration of melt beneath the rift axis, are critical to distinguish between these different scenarios and gain a better understanding of how volcanic rift zones evolve on geologic time-scales.

Lastly, slow-spreading mid-ocean ridge segments are frequently characterized by along-axis variations in crustal thickness as indicated by residual gravity anomalies [3840] and seismic velocity structure [37, 41-43]. Near the segment center, the rift valley is typically shallow, formed by closely spaced faults with relatively small throw $[6,35,44]$. Toward the segment end, faults become larger and more widely spaced, resulting in a 
broader, deeper rift valley with greater total relief. It has been proposed that the alongaxis variations in crustal thickness observed at many slow-spreading ridge segments can be explained by model in which dikes propagate outward from a central magma chamber located near the center of the ridge segment [45]. In this model, dike propagation is driven toward the ends of the spreading segment by the along-axis gradient in topographic relief, and the maximum propagation distance is limited by thermal arrest. However, the results of this study indicate that the growth in rift valley relief toward the ends of slow-spreading ridge segments will generate compressional stresses in the lower crust. If these stresses are large compared to the along-axis topographic driving stress, this may provide an alternative mechanism for limiting the along-axis propagation of dikes. It remains for future studies to fully investigate the 3-D interactions between dike propagation and fault development along a segmented rift system.

\section{Acknowledgements}

We thank Joe Cann, Ran Qin, Luc Lavier, and Laurent Montési for many fruitful discussions that help motivate this work. Comments by Cindy Ebinger, Scott King, and an anonymous reviewer significantly improved the overall clarity of this study. Funding for this research was provided by NSF Grants OCE 04-43246, OCE 05-50147, OCE 0242597 and OCE 04-26575, and a Carnegie Postdoctoral Fellowship to M.B. 


\section{Figure Captions}

Figure 1: Schematic illustration of stress conditions leading to intrusion of blade-like dikes. $\sigma_{\text {lith }}$ represents the lithostatic stress (compression positive) and $\sigma_{\text {tectonic }}$ is the total horizontal stress in the lithosphere. $\sigma_{\text {tectonic }}$ is defined by Byerlee's rule in the brittle crust and viscous flow in the underlying ductile region [46]. Thick dashed lines in left panel illustrate the location of the numerical domain shown in Figure 2. Dikes will propagate laterally if the driving pressure (difference between $\mathrm{P}_{\text {magma }}$ and $\sigma_{\text {tectonic }}$ ) at the dike center exceeds the driving pressure at the top and bottom of the dike. This condition will occur in magma limited rifting environments such as slow spreading ridges. Over geologic time a large proportion of laterally propagating dikes will not reach the surface, implying that a greater percentage of the total extension will be accommodated by magma accretion at the base of the plate than near the surface. Figure adapted from $[3,33]$.

Figure 2: Model setup for numerical simulations of dike intrusion in an extending viscoelastic layer. The dike injection zone is illustrated with the thick black line. Grey region represents the portion of the model space that undergoes brittle deformation, while the white region behaves viscously. Deformation is driven by applying a uniform horizontal velocity, $\mathrm{u}_{\text {tectonic }}$, to either side of the model space. Dike injection is simulated by widening a vertical column of elements in the center of the model space at a fixed rate $\mathrm{u}_{\text {dike }}$. The rate of magma injection is defined by $\mathrm{M}=\mathrm{u}_{\text {dike }} / \mathrm{u}_{\text {tectonic }}$.

Figure 3: (a) Vertical and (b) horizontal displacements calculated at the surface for a dike opening in a purely elastic layer (triangles). Displacements are normalized to the amount of dike opening. The dike is embedded in a $20 \mathrm{~km}$ thick elastic layer and extends from a depth of 3 to $6 \mathrm{~km}$. Thick black lines show the results of a 2-D boundary element solution [30]. (c) Horizontal deviatoric stress, $\sigma_{\mathrm{xx}}$, normalized by the dike opening.

Figure 4: Rate of topographic growth during the first $10 \mathrm{kyrs}$ of magmatic rifting as a function of the rate of magma injection, M. Curves illustrate dike heights of $2 \mathrm{~km}$ (circles), $3 \mathrm{~km}$ (triangles), and $4 \mathrm{~km}$ (squares). The relationship between the growth of rift topography and the rate of magma injection is a function of dike height. 
Figure 5: Numerical simulations of magmatic rifting showing the calculated strain-rate and horizontal deviatoric stress, $\sigma_{\mathrm{xx}}$, after $5 \mathrm{~km}(200 \mathrm{kyr})$ of total extension for $(\mathbf{a}, \mathbf{b}) \mathrm{M}=$ 1 and (c,d) $M=0.4$. The depth to the top of the dike injection zone is $2 \mathrm{~km}$ and the initial lithospheric thickness is $6 \mathrm{~km}$. For $\mathrm{M}=1$ two inward-dipping faults remain pinned at the top of the injection zone throughout rifting resulting in the formation of deep rift valley. Flexural stresses act to place the base of the plate in compression, which would act to inhibit further magma injection at that depth. In contrast for $M=0.4$, alternating inward and outward dipping faults form as extension continues, resulting in a shallow rift valley and tensile stresses throughout the axial lithosphere.

Figure 6: Rift valley depth (filled circles) and topographic (grey squares) and total horizontal deviatoric stress (open squares) at the base of the plate versus total extension for $M=1$. Topographic stresses are calculated by imposing model topography on a 6-km thick elastic plate with a Young's modulus of $30 \mathrm{GPa}$. Small-scale variations in the total stress curve are associated with the propagation of undamped elastic stresses throughout the model space. Note that the magnitude of compression at the base of the plate is directly correlated to the depth of the rift valley.

Figure 7: (a) Model topography and (b) horizontal deviatoric stress, $\sigma_{\mathrm{xx}}$, versus depth at the rift axis after $5 \mathrm{~km}$ (200 kyr) of total extension. (c) Horizontal deviatoric stress at the base of the plate versus the difference in $\mathrm{M}$ between the surface and base of the plate. Filled circles illustrate cases where the depth to top of the dike is $2 \mathrm{~km}$ and $\mathrm{M}$ is constant within the injection zone. Triangles illustrate runs where $M$ varies linearly with depth from the surface to the base of the plate with $\mathrm{M}_{\text {surface }}=0$ (blue) and $\mathrm{M}_{\text {surface }}=0.25$ (red). Note that for $\Delta \mathrm{M}>0.5-0.7$ continuous magma injection is inhibited by compression at the base of the plate.

Figure 8: Comparison of stress conditions for rifts with and without the influence of rift topography. $\sigma_{\text {lith }}$ represents the lithostatic stress and $\sigma_{\text {tectonic }}$ is the total horizontal stress in the lithosphere, which is controlled by a combination of brittle and ductile failure and the growth of topography. As the rift topography reduces the tensile stress at the base of the plate, dikes with the same driving pressure, $\mathrm{P}_{\text {drive }}$, will propagate upward to shallower 
levels in the crust. The net result is to suppress the formation of blade-like dikes and reduce the total gradient in magma accretion throughout the crust. 


\section{References}

[1] R.S. Fiske, E.D. Jackson, Orientation and growth of Hawaiian volcanic rifts: the effect of regional structure and gravitational stresses, Proc. R. Soc. Lond. A 329(1972) 299-326.

[2] A.M. Rubin, D.D. Pollard, Origin of blade-like dikes in volcanic rift zones, in: R.W. Decker, T.L. Wright, P.H. Stauffer, (Eds), Volcanism in Hawaii Professional Paper 1350, U.S. Geol. Surv., 1987, pp. 1449-1470.

[3] A.M. Rubin, Propagation of magma-filled cracks, Annu. Rev. Earth Planet. Sci. 23(1995) 287-336.

[4] M.P. Ryan, Neutral buoyancy and the mechanical evolution of magmatic systems, in: B.O. Mysen, (Ed), Magmatic Processes: Physicochemical Principles Spec. Pub. 1, Geochem. Soc., 1987, pp. 259-287.

[5] S.C. Solomon, P.Y. Huang, L. Meinke, The seismic moment budget of slowly spreading ridges, Nature 334(1988) 58-60.

[6] J. Escartín, P.A. Cowie, R.C. Searle, S. Allerton, N.C. Mitchell, C.J. Macleod, A.P. Slootweg, Quantifying tectonic strain and magmatic accretion at a slow spreading ridge segment, Mid-Atlantic Ridge, $29^{\circ}$ N, J. Geophys. Res. 104(1999) 10,42110,437 .

[7] A.M. Rubin, D.D. Pollard, Dike-induced faulting in rift zones of Iceland and Afar, Geology 16(1988) 413-417.

[8] D.D. Pollard, P.T. Delaney, W.A. Duffield, E.T. Endo, A.T. Okamura, Surface deformation in volcanic rift zones, Tectonophys. 94(1983) 541-584.

[9] J.M. Bull, T.A. Minshull, N.C. Mitchell, K. Thors, J.K. Dix, A.I. Best, Fault and magmatic interaction within Iceland's western rift over the last 9 kyr, Geophys. J. Int. 154(2003) F1-F8.

[10] T. Tentler, Propagation of brittle failure triggered by magma in Iceland, Tectonophys. 406(2005) 17-38.

[11] A. Björnsson, K. Saemundsson, P. Einarsson, E. Tryggvason, K. Gronvald, Current rifting episode in north Iceland, Nature 266(1977) 318-323.

[12] E. Tryggvason, The widening of the Krafla fissure swarm during the 1975-1981 volcano-tectonic episode, Bull. Volcanol. 47(1984) 47-69.

[13] J.-C. Sempéré, J. Lin, H.S. Brown, H. Schouten, G.M. Purdy, Segmentation and morphotectonic variations along a slow-spreading center: The Mid-Atlantic ridge $\left(24^{\circ} 00^{\prime} \mathrm{N}-30^{\circ} 40^{\prime} \mathrm{N}\right)$, Mar. Geophys. Res. 15(1993) 153-200.

[14] K.C. Macdonald, The crest of the Mid-Atlantic Ridge: Models for crustal generation processes and tectonics, in: P.R. Vogt, B.E. Tucholke, (Eds), The Geology of North America The Western North Atlantic Region, v. M, Geological Society of America, 1986, pp. 51-68.

[15] A.M. Rubin, Dike-induced faulting and graben subsidence in volcanic rift zones, J. Geophys. Res. 97(1992) 1839-1858.

[16] A. Gudmundsson, Surface stresses associated with arrested dykes in rift zones, Bull. Volcanol. 65(2003) 606-619.

[17] A. Gudmundsson, Loetveit, Dyke emplacement in a layered and faulted rift zone, J. Volc. Geotherm. Res. 144(2005) 311-327. 
[18] D. Curewitz, J.A. Karson, Geological consequences of dike intrusion at mid-ocean ridge spreading centers, in: W.R. Buck, P.T. Delaney, J.A. Karson, Y. Lagabrielle, (Eds), Faulting and Magmatism at Mid-Ocean Ridges Geophys. Mono. 106, Am. Geophys. Union, Washington, D.C., 1998, pp. 117-136.

[19] P.A. Cundall, Numerical experiments on localization in frictional materials, Ing. Arch. 58(1989) 148-159.

[20] R. Hassani, J. Chéry, Anelasticity explains topography associated with Basin and Range normal faulting, Geology 24(1996) 1095-1098.

[21] A.N.B. Poliakov, W.R. Buck, Mechanics of strectching elastic-plastic-viscous layers: Applications to slow-spreading mid-ocean ridges, in: W.R. Buck, P.T. Delaney, J.A. Karson, Y. Lagabrielle, (Eds), Faulting and Magmatism at MidOcean Ridges Geophys. Mono. 106, AGU, Washington, D.C., 1998, pp. 305-323.

[22] L.L. Lavier, W.R. Buck, A.N.B. Poliakov, Factors controlling normal fault offset in an ideal brittle layer, J. Geophys. Res. 105(2000) 23,431-23,442.

[23] A.N.B. Poliakov, An explicit inertial method for the simulation of viscoelastic flow: An evaluation of elastic effects on diapiric flow in two- and three-layers models, in: D.B. Stone, S.K. Runcorn, (Eds), Flow and Creep in the Solar System: Observations, Modeling and Theory, Kluwer Acad. Pub., 1993, pp. 175-195.

[24] L.L. Lavier, W.R. Buck, Half graben versus large-offset low-angle normal fault: Importance of keeping cool during normal faulting, J. Geophys. Res. 107(2002) 10.1029/2001JB000513.

[25] S.H. Kirby, Rheology of the Lithosphere, Rev. Geophys. and Space Phys. 21(1983) 1458-1487.

[26] D.L. Kohlstedt, B. Evans, S.J. Mackwell, Strength of the lithosphere: Constraints imposed by laboratory experiments, J. Geophys. Res. 100(1995) 17,587-17,602.

[27] S.J. Mackwell, M.E. Zimmerman, D.L. Kohlstedt, High-temperature deformation of dry diabase with application to tectonics on Venus, J. Geophys. Res. 103(1998) 975-984.

[28] G. Hirth, J. Escartín, J. Lin, The rheology of the lower oceanic crust: Implications for lithospheric deformation at mid-ocean ridges, in: W.R. Buck, P.T. Delaney, J.A. Karson, Y. Lagabrielle, (Eds), Faulting and Magmatism at Mid-Ocean Ridges Geophys. Mono. 106, AGU, Washington, D.C., 1998, pp. 291-304.

[29] W.R. Buck, L.L. Lavier, A.N.B. Poliakov, Modes of faulting at mid-ocean ridges, Nature 434(2005) 719-723.

[30] S.L. Crouch, A.M. Starfield, Boundary Element Methods in Solid Mechanics, Unwin Hyman, London, 1990, 322 pp.

[31] R. Qin, W.R. Buck, Effect of lithospheric geometry on rift valley relief, J. Geophys. Res. 110(2005) doi:10.1029/2004JB003411.

[32] S.M. Carbotte, K.C. Macdonald, Causes of variation in fault-facing direction on the ocean floor, Geology 18(1990) 749-752.

[33] A.M. Rubin, A comparison of rift-zone tectonics in Iceland and Hawaii, Bull. Volcanol. 52(1990) 302-319.

[34] A.B. Watts, Isostasy and Flexure of the Lithosphere, Cambridge University Press, Cambridge, 2001, 458 pp.

[35] P.R. Shaw, J. Lin, Causes and consequences of variations in faulting style at the Mid-Atlantic Ridge, J. Geophys. Res. 98(1993) 21,839-21,851. 
[36] W.J. Shaw, J. Lin, Models of ocean ridge lithospheric deformation: Dependence on crustal thickness, spreading rate, and segmentation, J. Geophys. Res. 101(1996) 17,977-17,993.

[37] E.E.E. Hooft, R.S. Detrick, D.R. Toomey, J.A. Collins, J. Lin, Crustal thickness and structure along three contrasting spreading segments of the Mid-Atlantic Ridge, $33.5^{\circ}-35^{\circ}$ N, J. Geophys. Res. 105(2000) 8205-8226.

[38] B. Kuo, D.W. Forsyth, Gravity anomalies of the ridge-transform system in the South Atlantic between $31^{\circ}$ and $34.5^{\circ} \mathrm{S}$ : Upwelling centers and variations in crustal thickness, Mar. Geophys. Res. 10(1988) 205-232.

[39] J. Lin, G.M. Purdy, H. Schouten, J.-C. Sempéré, C. Zervas, Evidence from gravity data for focused magmatic accretion along the Mid-Atlantic ridge, Nature 344(1990) 627-632.

[40] R.S. Detrick, H.D. Needham, V. Renard, Gravity anomalies and crustal thickness variations along the Mid-Atlantic Ridge between $33^{\circ} \mathrm{N}$ and $40^{\circ} \mathrm{N}, \mathrm{J}$. Geophys. Res. 100(1995) 3767-3787.

[41] M. Tolstoy, A.J. Harding, J.A. Orcutt, Crustal thickness on the Mid-Atlantic Ridge: Bull's-eye gravity anomalies and focused accretion, Science 262(1993) 726-729.

[42] A. Hosford, J. Lin, R.S. Detrick, Crustal evolution over the last 2 m.y. at the MidAtlantic Ridge OH-1 segment, 35² N, J. Geophys. Res. 106(2001) 13,269-13,285.

[43] J.P. Canales, R.S. Detrick, J. Lin, J.A. Collins, D.R. Toomey, Crustal and upper mantle seismic structure beneath the rift mountains and across a nontransform offset at the Mid-Atlantic Ridge (35N), J. Geophys. Res. 105(2000) 2699-2719.

[44] R.C. Searle, P.A. Cowie, N.C. Mitchell, S. Allerton, C.J. MacLeod, J. Escartin, S.M. Russell, P.A. Slootweg, T. Tanaka, Fault structure and detailed evolution of a slow spreading ridge segment: the Mid-Atlantic Ridge at $29^{\circ} \mathrm{N}$, Earth Planet. Sci. Lett. 154(1998) 167-183.

[45] Y.A. Fialko, A.M. Rubin, Thermodynamics of lateral dike propagation: Implications for crustal accretion at slow spreading mid-ocean ridges, J. Geophys. Res. 103(1998) 2501-2514.

[46] S.H. Kirby, A.K. Kronenberg, Rheology of the lithosphere: Selected topics, Rev. Geophys. 25(1987) 1219-1244. 


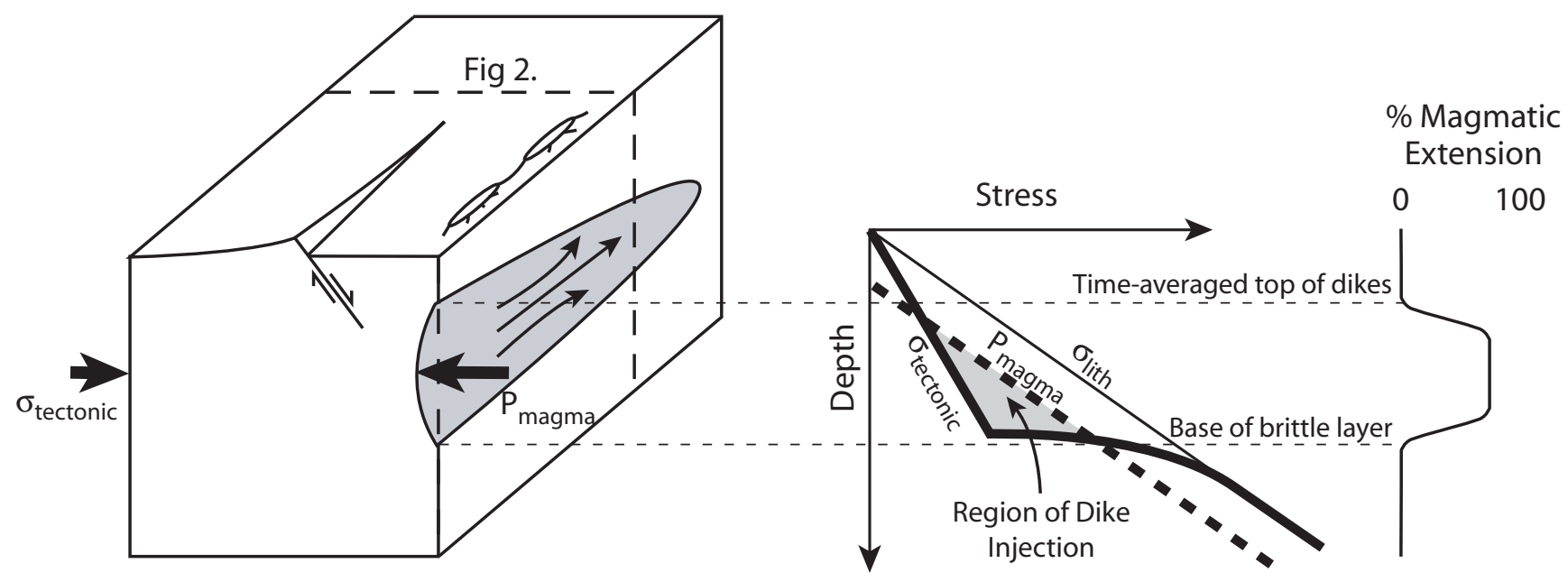

Figure 1 


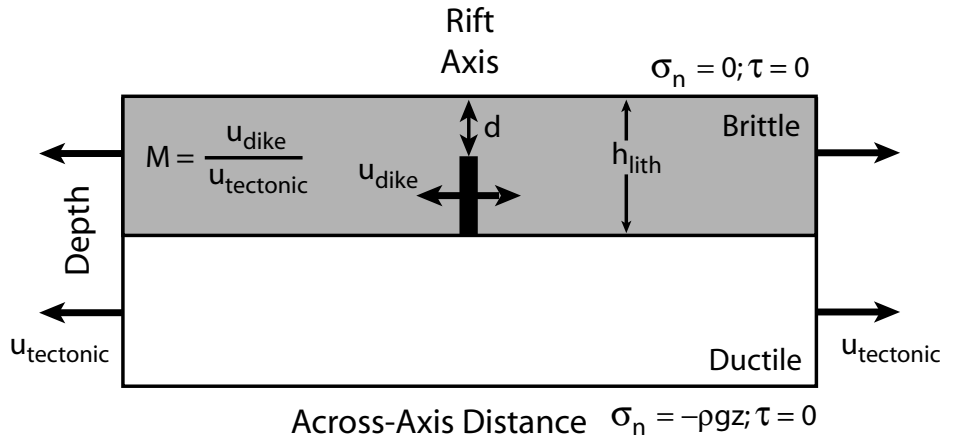

Figure 2 

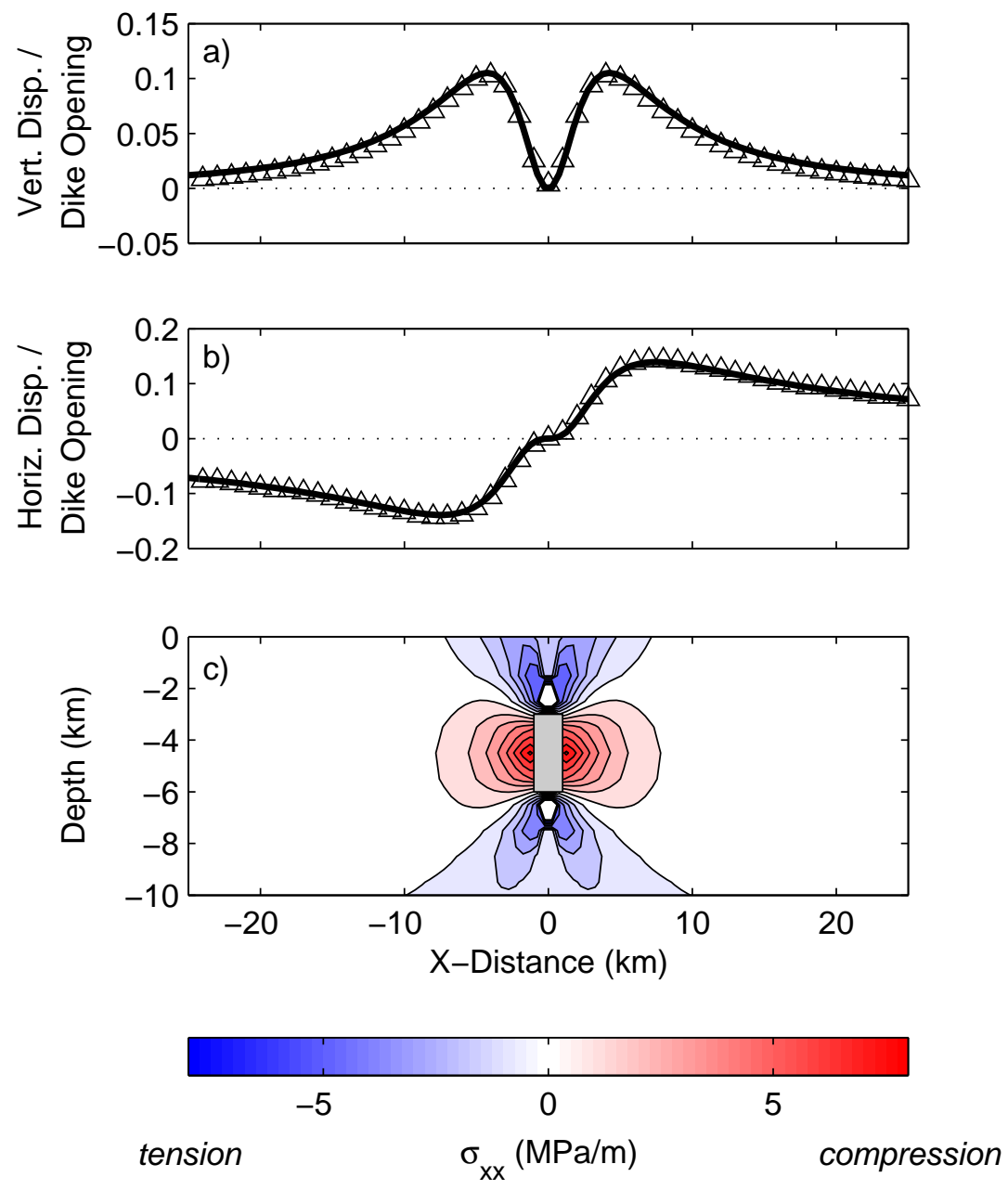

Figure 3 


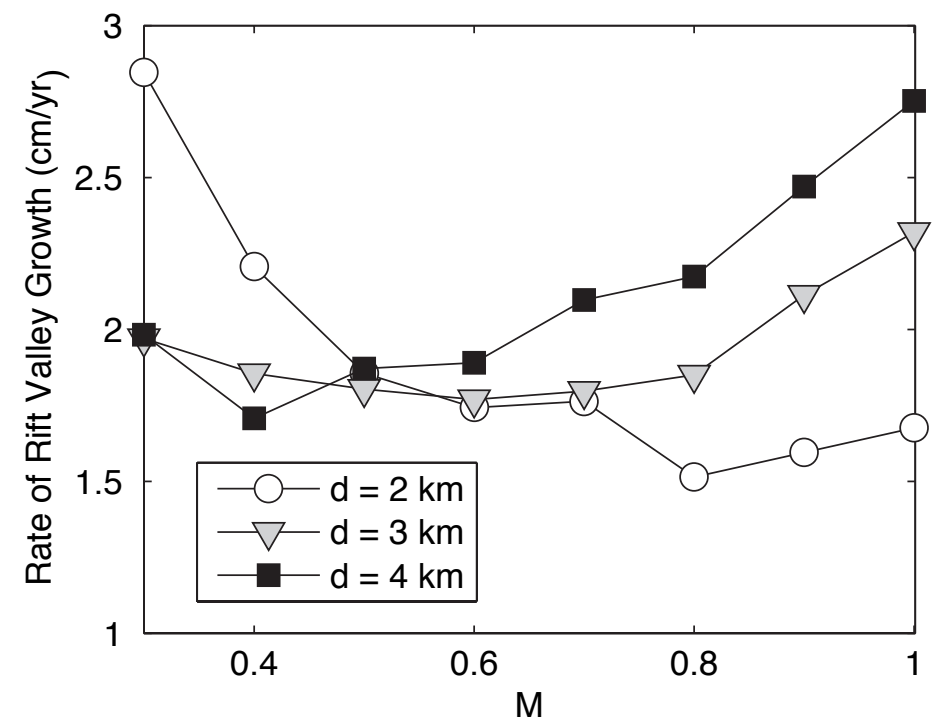

Figure 4 


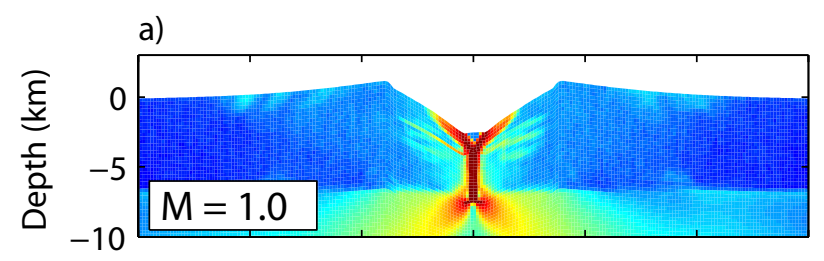

b)
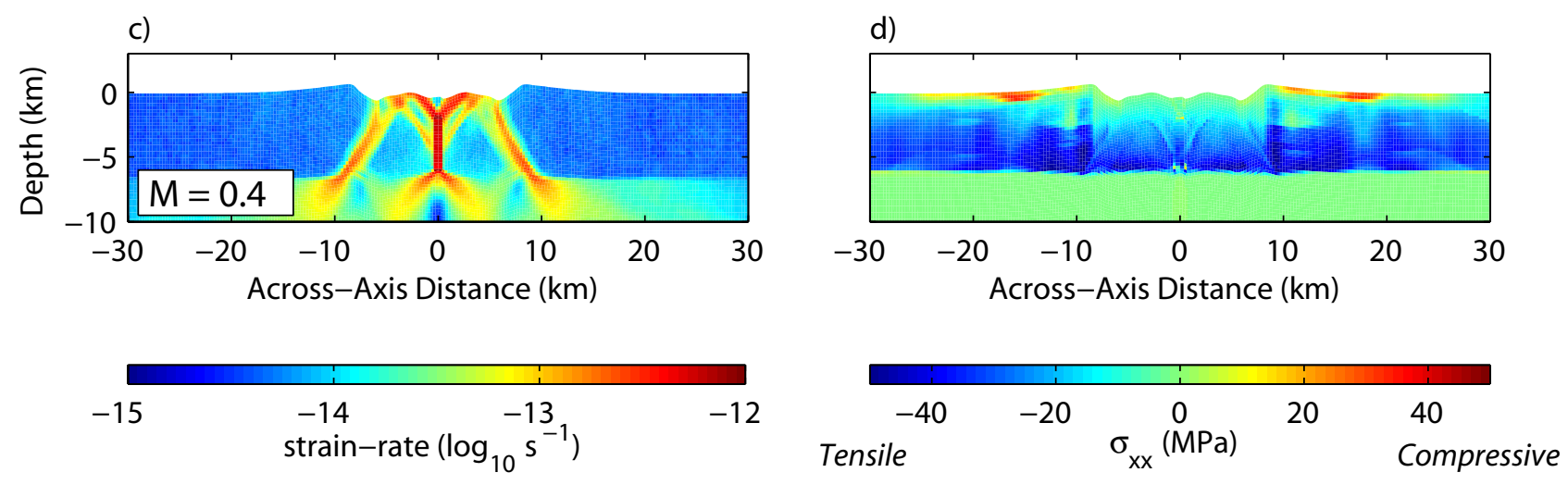

Figure 5 


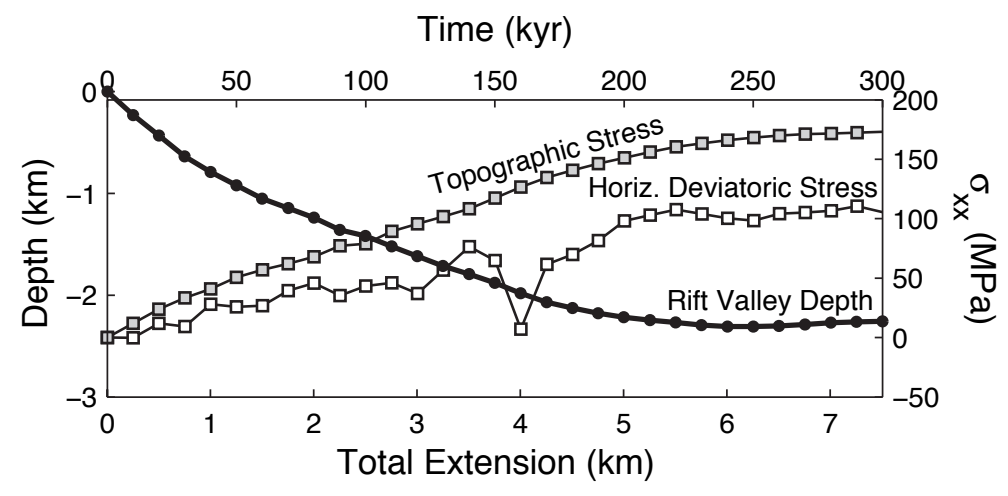

Figure 6 

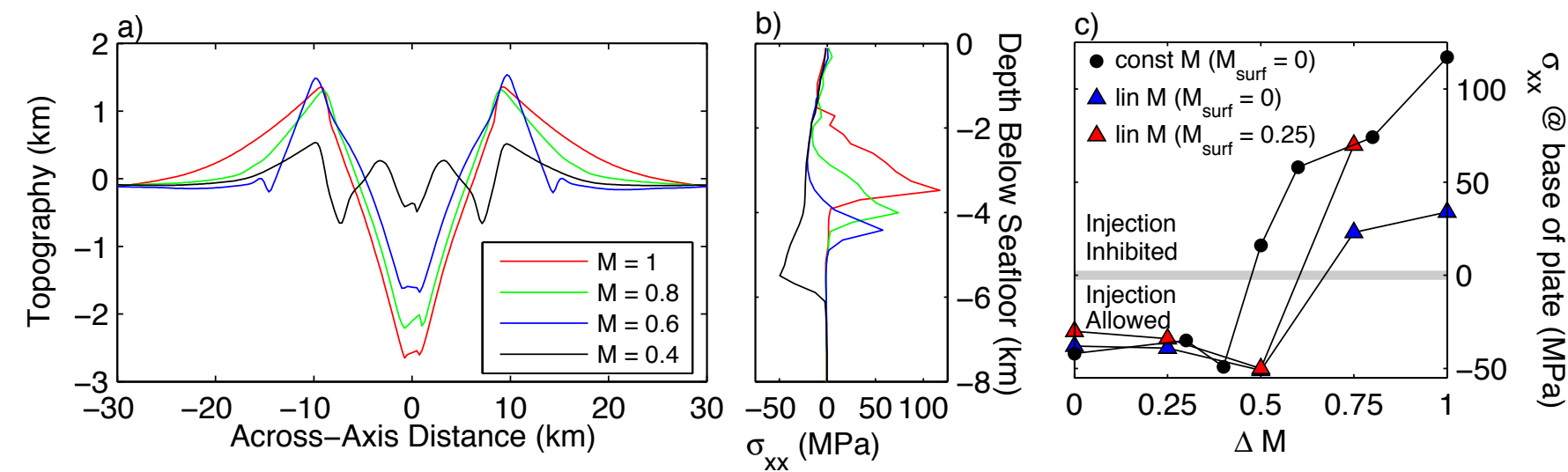

Figure 7 


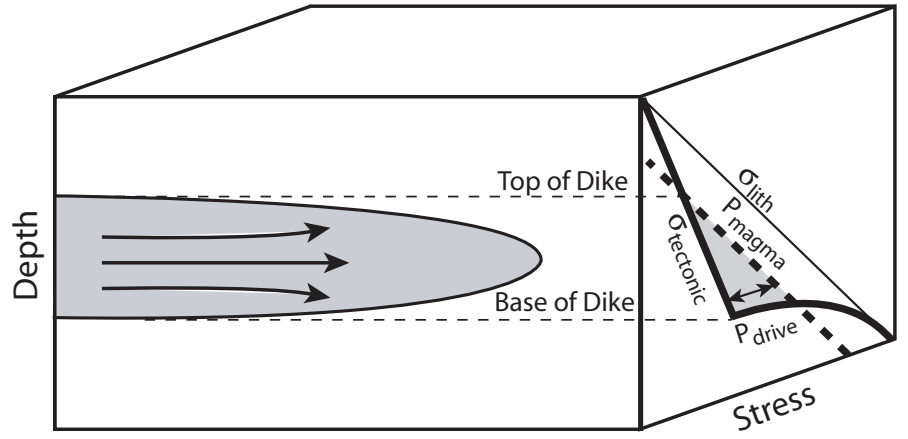

Along-Rift Distance
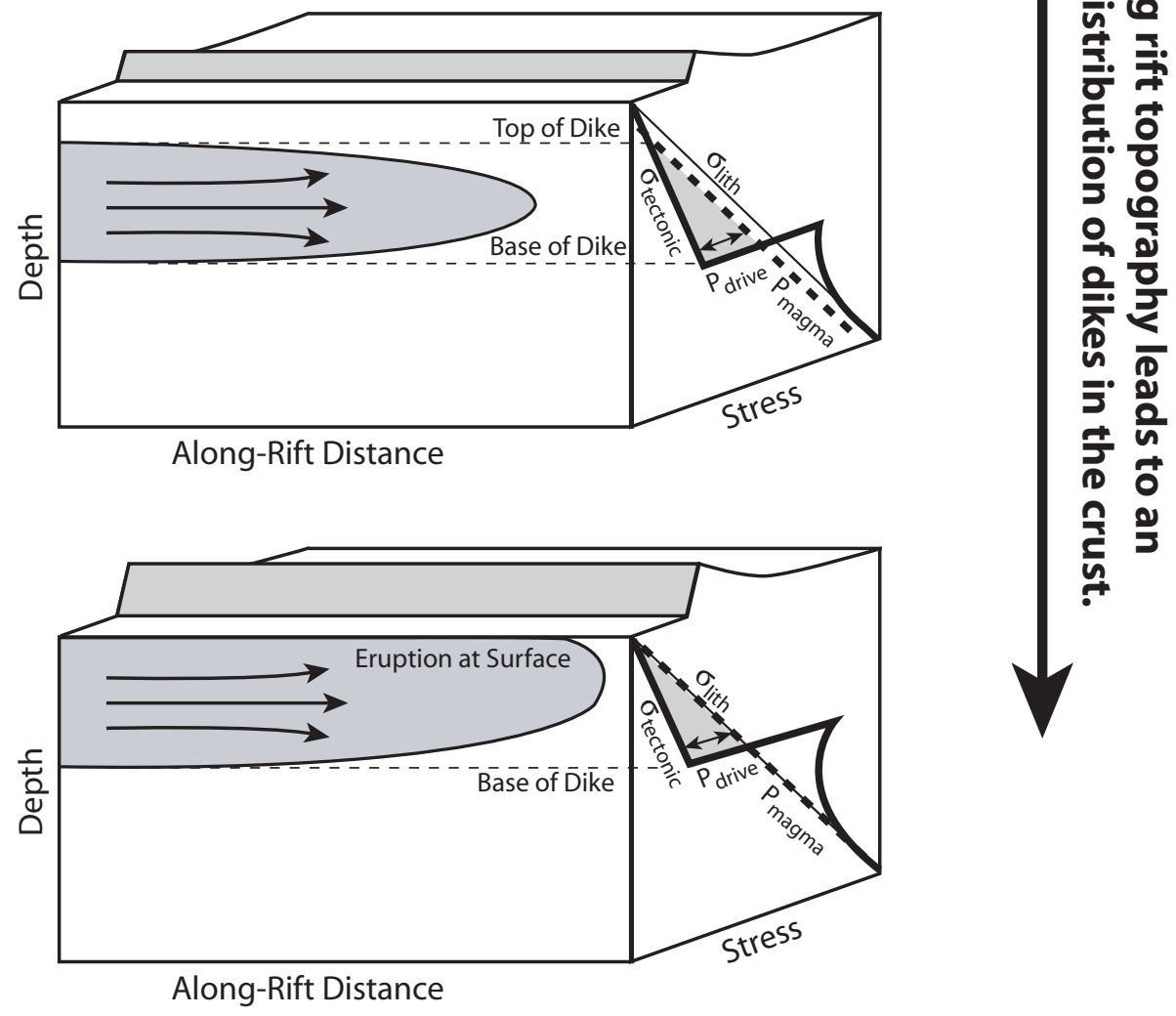

Figure 8 